\title{
ВЛАСТИВОСТІ ЛИЧКОВАНИХ ДЕРЕВИННО-ПОЛІМЕРНИХ МАТЕРІАЛІВ ПЛОСКОГО СПОСОБУ ПРЕСУВАННЯ
}

Досліджено прочес личкування деревинно-полімерних матеріалів (ДПМ) плоского способу пресування. Личкування ДПМ здійснено одночасно з їх пресуванням. Для личкування використано декоративний ламінат високого тиску (HPL) товщиною 0,5 мм. Як клей для приклеювання HPL використано поліетиленову (ПЕ) плівку або вторинний поліетилен низької щільності (ВПЕ). Для порівняння виготовлено личковані ДПМ без використання клею для приклеювання HPL. Встановлено, що тип клею не має істотного впливу на механічні показники ДПМ. Межа міџності під час статичного згинання у разі використання ВПЕ зростає на 14\%, а у разі використання ПЕ плівки - на 24\%, порівняно із личкованими ДПМ без використання клею для приклеювання HPL. Аналогічні залежності спостережено і для модуля пружності під час статичного згинання. Тип клею для приклеювання HPL також не має визначального впливу на межу міџності під час розтягування перпендикулярно до площини плити. Набрякання за товщииною значно зменшується із використанням клею, особливо це проявляється під час занурення взіриів у воду на 24 год. У разі використання ПЕ плівки та ВПЕ отримано практично однакові результати набрякання за товщиною, як за 2, так $і$ за 24 год занурення.

Ключові слова: деревинно-полімерний матеріал, личкування, поліетиленова плівка, вторинний поліетилен низької щільності, декоративний ламінат високого тиску, плоске пресування

Постановка проблеми. Деревинно-полімерні матеріали (ДПМ) - це перспективний матеріал, який характеризується добрими експлуатаційними властивостями та використанням у різних галузях промисловості [1]. Залежно від конфігурації та сфери використання кінцевого виробу ДПМ виготовляють різними способами: екструзією, литтям під тиском, компресійним пресуванням та ін. [2]. Найпоширенішим способом виготовлення ДПМ у США та Європі є екструзія [3]. Однак спосіб екструзії дає змогу виготовляти погонажні ДПМ із обмеженим поперечним перерізом. ДПМ також можна виготовляти плоским пресуванням у гарячих пресах [1]. Однак у процесі виготовлення ДПМ плоским способом важко досягнути рівномірного перемішування компонентів композиції, а особливо втримування полімеру на поверхні деревинних частинок без додавання спеціальних агентів зчеплення. Як наслідок, ускладнюється формування деревиннополімерного килима рівномірної структури (частинки полімеру просипаються до нижнього шару, порушуючи структуру килима за його товщиною), що призводить до погіршання механічних властивостей ДПМ, зокрема міцності під час статичного згинання. Підвищення показників міцності можна досягти шляхом введення до деревинно-полімерної композиції різного роду модифікувальних добавок [4]. Окрім того, для підвищення показників міцності під час статичного згинання можна використовувати й армувальні личкувальні матеріали. Зокрема, у дослідженні [5] два різних типи термопластичних армувальних матеріалів (Twintex - змішана армувальна тканина 3 термопластичними та скляними волокнами; S-TEX - склотканинний армований поліпропілен 3 хаотично орієнтованих скляних волокон) використано як поверхневі шари для покриття ДПМ. Опорядження ДПМ можна також здійснювати матеріалами, які зазвичай використовують для стружкових плит (СП) [6, 7]. Зокрема, можливість виготовлення личкованих натуральним шпоном СП різними способами досліджено в роботі [8]. Використання натурального шпону для опорядження поверхні ДПМ здійснено і в роботі [9]. Для цього використано березовий лущений шпон і дубовий струганий шпон. Причому процес пресування і личкування відбувався одночасно. Значним недоліком використання натурального шпону є різке зниження водостійкості ДПМ.

\footnotetext{
1 ЛЮТИЙ Павло Володимирович - кандидат технічних наук, асистент кафедри технологій деревинних композиційних матеріалів, целюлози та паперу, Національний лісотехнічний університет України, м. Львів, Україна. Тел.: +38(032) 238-44-99. E-mail: lyutyj_p@nltu.edu.ua

2 БЕХТА Павло Антонович - дійсний член ЛАН України, доктор технічних наук, професор, завідувач кафедрою технологій деревинних композиційних матеріалів, целюлози та паперу, Національний лісотехнічний університет України, м. Львів, Україна. Тел.: +38(032) 238-44-99, Факс:+38(032) 237-89-05. E-mail: bekhta@ukr.net

3 ОРТИНСЬКА Галина Євгенівна - кандидат технічних наук, старший викладач кафедри технологій деревинних композиційних матеріалів, целюлози та паперу, Національний лісотехнічний університет України, м. Львів, Україна. Тел.: +38(032) 23844-99. E-mail: ortynska_g@nltu.edu.ua
} 
Наукові праці Лісівничої академії наук України: збірник наукових праць

Незважаючи на дослідження з личкування ДПМ плоским способом пресування, їх фізичні і механічні властивості можна поліпшити шляхом покриття їх поверхні декоративними матеріалами, зокрема декоративним ламінатом високого тиску (HPL), що може значно розширити галузі їх застосування. Тому мета цього дослідження полягала у вивченні властивостей ДПМ, отриманих плоским способом пресування з одночасним їх личкуванням HPL.

Матеріали та методика дослідження. Для виконання експериментальних досліджень використано такі матеріали: деревинна стружка вологістю 2-3\%, поліетиленова (ПЕ) плівка, частинки вторинного поліетилену низької щільності (ВПЕ), декоративний ламінат високого тиску (HPL) товщиною 0,5 мм. ПЕ плівку і ВПЕ застосовували як клей для приклеювання HPL до поверхні ДПМ. Крім того, для порівняння, личкували ДПМ декоративним ламінатом високого тиску без використання будь-якого клею. Фракційний склад деревинних частинок та ВПЕ наведено у табл. 1.

Співвідношення між деревинною стружкою та ВПЕ становило 60:40. Процес виготовлення личкованих ДПМ представлено на рис. 1.
Таблиия 1 Фракційний склад деревинних частинок та ВПЕ

\begin{tabular}{|c|c|c|c|c|c|c|c|}
\hline $\begin{array}{c}\text { Ком- } \\
\text { по- } \\
\text { нент }\end{array}$ & $-/ 5$ & $5 / 4$ & $4 / 2$ & $2 / 1$ & $1 / 0,63$ & $0,63 / 0,315$ & $0,315 / 0$ \\
\hline $\begin{array}{l}\text { Дере- } \\
\text { винна } \\
\text { стру- } \\
\text { жка }\end{array}$ & 4,75 & 12,2 & 15,79 & 40,28 & 15,67 & 9,13 & 2,18 \\
\hline ВПЕ & 9,53 & 3,04 & 53,14 & 32,45 & 1,83 & - & - \\
\hline
\end{tabular}

Змішування компонентів композиції ДПМ здійснювали в сухому стані впродовж 10 хв. Отриману деревинно-полімерну композицію формували на HPL листі, попередньо на який наносили клей у вигляді ВПЕ, ПЕ плівки або взагалі клей не використовували. Зверху на деревинно-полімерну композицію знову наносили клей (ВПЕ, ПЕ плівку або без клею) та HPL лист. Після чого сформований пакет піддавався гарячому пресування за температури $180^{\circ} \mathrm{C}$, тиску 3,5 МПа, впродовж 8,0 хв. Після закінчення гарячого пресування личкований ДПМ охолоджували під тиском до температури $30-40^{\circ} \mathrm{C}$. Розміри личкованих ДПМ становили 250x230x8 мм, а прогнозована щільність 800 кг/ $\mathrm{M}^{3}$.

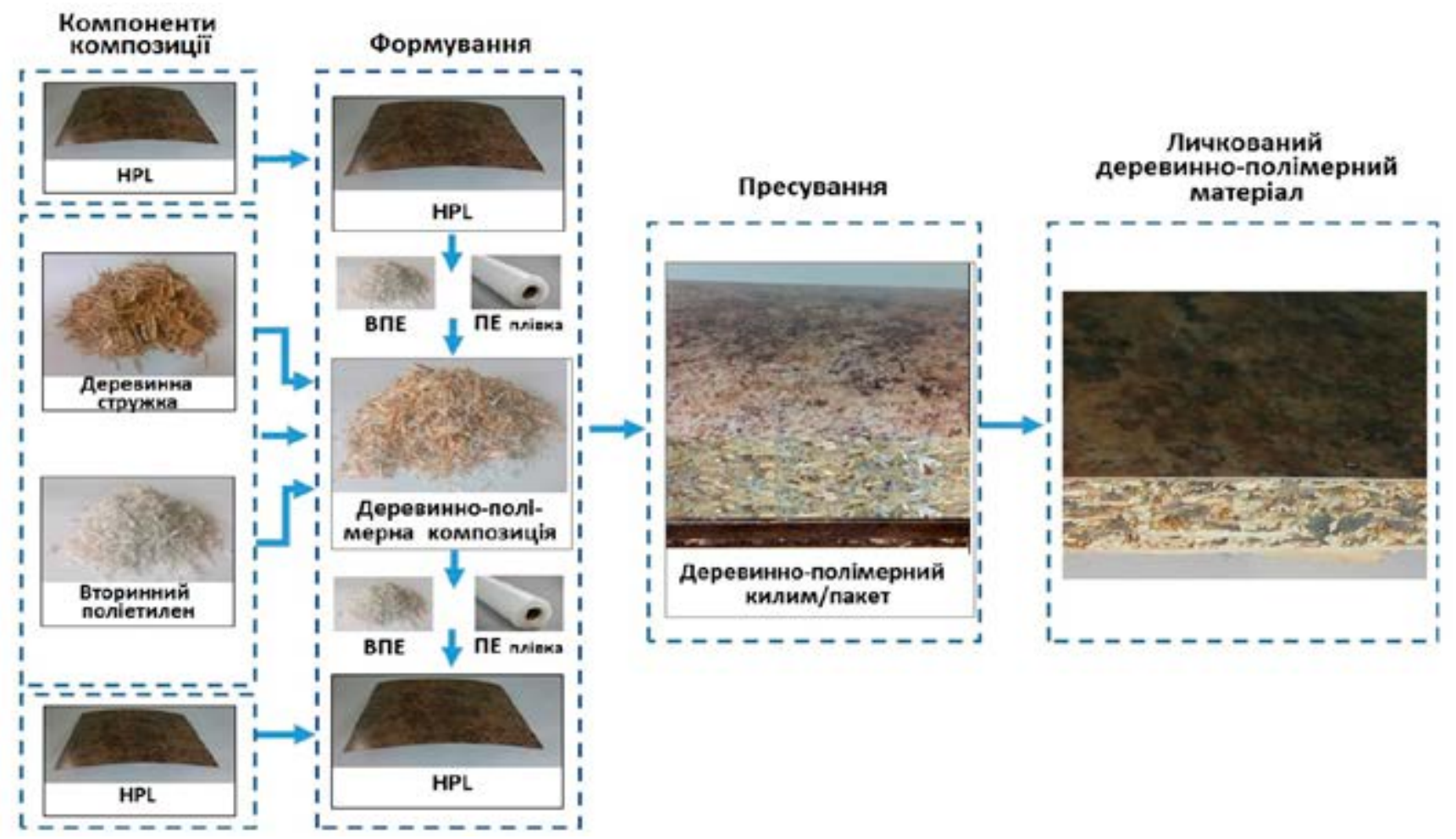

Рис. 1. Процес виготовлення личкованих ДПМ

Для встановлення фізико-механічних показників личкованих ДПМ використано стандарті методики, а саме ДСТУ ЕN 310 для визначення межі міцності та модуля пружності під час статичного згинання, ДСТУ ISO 16984 - межі міцності під час розтягування перпендикулярно до площини плити, ДСТУ 4761 - набрякання за товщиною за 2 та 24 год.
Результати дослідження. Встановлено, що використання клею для приклеювання HPL хоча й дає змогу підвищити межу міцності під час статичного згинання (рис. 2), але цей вплив не є істотним (табл. 2). Зокрема, межа міцності під час статичного згинання у разі використання ВПЕ зростає на $14 \%$, а у разі використання ПЕ плівки - на $24 \%$, порівняно із личкованими ДПМ без клею. 
Результати ANOVA тесту

\begin{tabular}{|c|c|c|c|c|c|c|}
\hline $\begin{array}{r}\text { Змін } \\
\text { фаг }\end{array}$ & Досліджуваний показник & SS & df & $\begin{array}{l}\text { Mean } \\
\text { Square }\end{array}$ & $\mathrm{F}$ & Sig. F \\
\hline \multirow{5}{*}{$\begin{array}{c}\text { Тип клею } \\
\text { для при- } \\
\text { клеювання } \\
\text { HPL }\end{array}$} & Межа міцності г & 127,733 & 2 & 63,866 & 3,477 & 0,057 \\
\hline & Модуль пружності & 286207,53 & 2 & 43103,769 & 2,040 & 0,165 \\
\hline & $\begin{array}{l}\text { Межа міцност } \\
\text { перпендикуля }\end{array}$ & 0,0 & 2 & $10-5$ & 0,228 & 0,798 \\
\hline & Набрякання за товщиною (2 год занурення) & 0,132 & 2 & 0,066 & 0,177 & 0,839 \\
\hline & Набрякання за товщиною (24 год занурення) & 122,678 & 2 & 61,339 & 58,600 & 0,000 \\
\hline
\end{tabular}

Примітка: SS - сума квадратів; df - ступінь вільності; MS - середній квадрат; F - критерій Фішера; Sig. F - значущість фактора

Аналогічні залежності встановлено й під час визначення модуля пружності під час статичного згинання (рис. 3). Зокрема, під час личкування ДПМ без використання клею існує безпосередній контакт між HPL та деревинно-полімерною композицією (в якій домінують деревинні частинки). Відповідно, цей контакт не сприяє утворенню міцного адгезійного з'єднання та під час випробування відбувається швидке його руйнування. Використання ж клею сприяє утворенню міцнішого адгезійного зв'язку. До того ж, під час використання ПЕ плівки міцність є дещо вищою порівняно із ВПЕ. Це зумовлено рівномірним контактом між

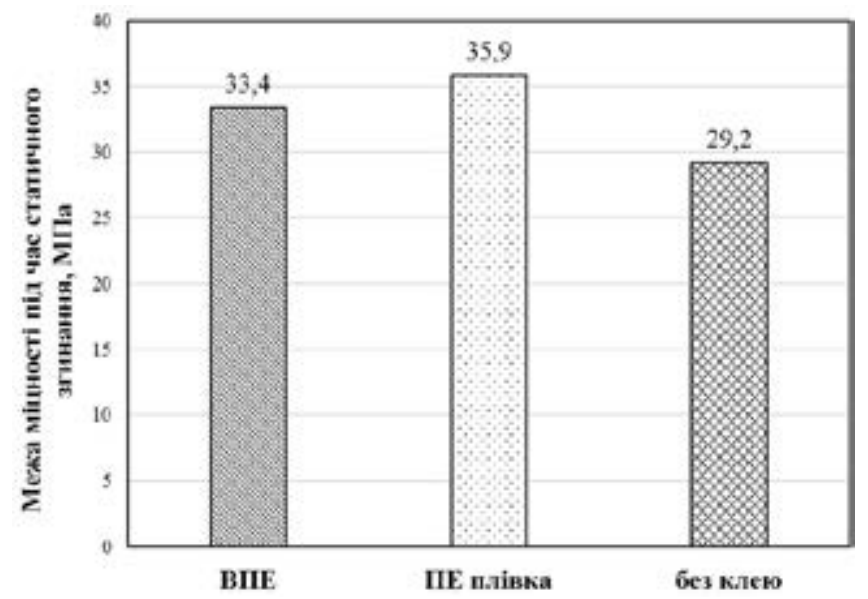

Рис. 2. Межа міцності під час статичного згинання личкованих ДПМ

Відповідно, використання HPL для личкування ДПМ дає змогу отримувати композиційний матеріал із однорідними показниками міцності в обох напрямках.

Вплив типу клею для приклеювання HPL також не має визначального впливу на межу міцності під час розтягування перпендикулярно до площини плити, що підтверджено ANOVA (див. табл. 2), а також на рис. 4. Це можна пояснити тим, що межа міцності під час розтягування перпендикулярно до площини плити характеризує міцність склеювання між собою частинок саме внутрішнього шару, а використання клею для приклеювання HPL аж ніяк не впливає на структуру чи процес склеювання вну-
HPL i ПЕ плівкою, що дає змогу отримати ДПМ 3 однорідним розподіленням міцності по всій площині.

Однак, якщо порівнювати отримані значення 3 показниками міцності під час статичного згинання ДПМ личкованих натуральним шпоном, то вони $\epsilon$ неоднозначними [9]. ДПМ личковані натуральним шпоном характеризуються значно вищими показниками міцності (у 1,31-1,63 рази) під час випробування впоперек волокон шпону, однак при цьому значно меншими під час випробування вздовж шпону (у 2,2-2,8 рази), що пояснюється природою личкувального матеріалу.

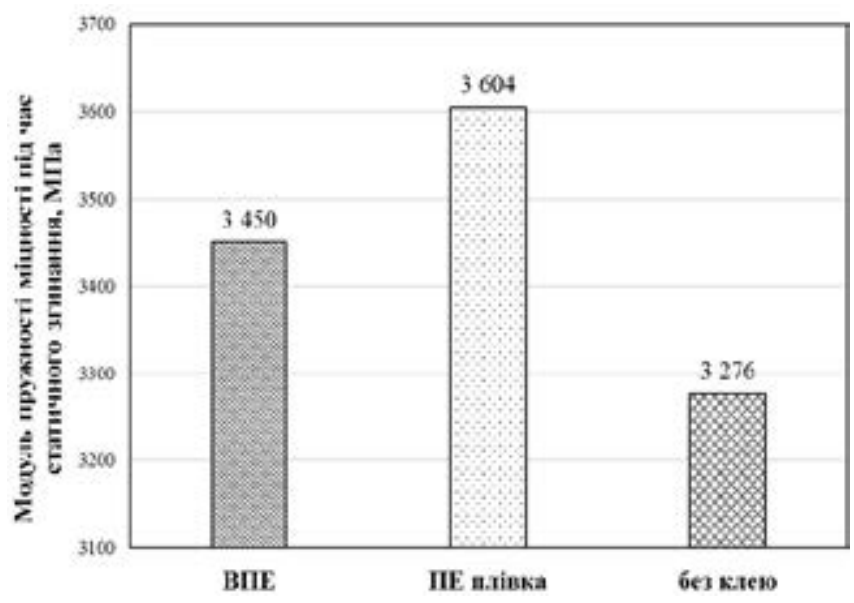

Рис. 3. Модуль пружності під час статичного згинання личкованих ДПМ

трішнього шару. Однак, якщо проаналізувати отримані значення, то варто зауважити, що вони є доволі високими.

Наявність клею між деревинно-полімерною композицією та HPL значно впливає на водостійкість личкованих ДПМ (рис. 5), але тільки на набрякання після занурення у воді впродовж 24 год (див. табл. 2). Набрякання за товщиною після 2 год занурення у воді у всіх личкованих ДПМ практично однакове і знаходиться нижче показника $1 \%$, що також підтверджено ANOVA (див. табл. 2). Однак із збільшенням тривалості занурення взірців до 24 год характер впливу типу клею стає більш вираженим. 
Наукові праці Лісівничої академії наук України: збірник наукових праць

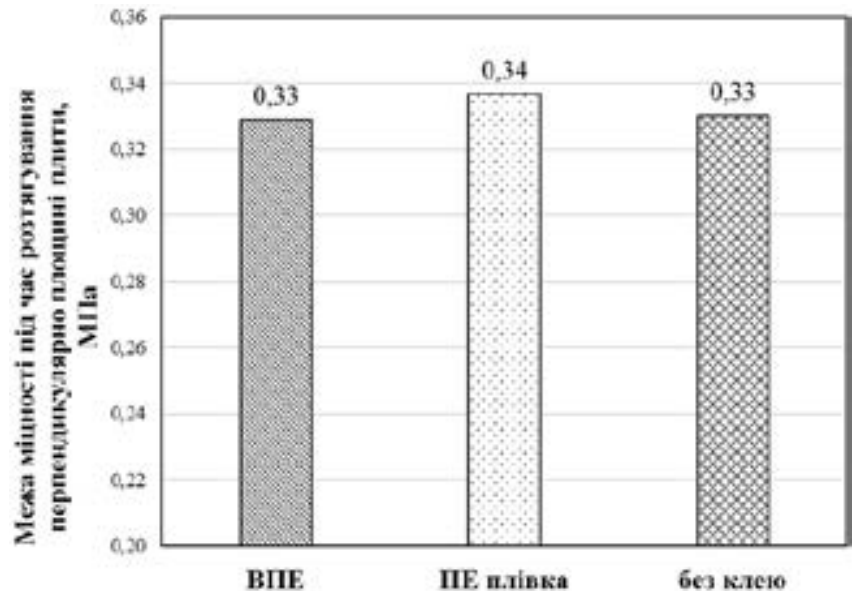

Рис. 4. Межа міцності під час розтягування перпендикулярно до площини плити личкованих ДПМ

Зокрема, у разі використання ВПЕ набрякання за товщиною (за 24 год занурення) зменшується в 1,6 раза, а у разі використання ПЕ плівки - в 1,63 раза, порівняно 3 личкованими ДПМ без використання клею для приклеювання HPL. Також варто зауважити, що у разі використання ПЕ плівки та ВПЕ спостерігаються практично однакові результати набрякання за товщиною як за 2, так і за 24 год занурення. Якщо ж порівняти отримані результати водостійкості личкованих HPL із натуральним шпоном [9], то треба зауважити, що використання HPL дає змогу значно зменшити показники набрякання за товщиною. Зокрема, набрякання за товщиною при цьому зменшується в 1,5-2,42 рази, залежно від типу використаного шпону (лущеного березового чи струганого дубового). Це можна пояснити природою личкувальних матеріалів, використаних у дослідженнях [9]. Натуральний шпон, володіючи властивостями деревини, доволі легко поглинає воду і змінює свої геометричні розміри під іiі впливом. Згідно з EN 438-1, HPL - це матеріал, який складається із шарів целюлозного волокна (зазвичай, папір), просоченого термореактивними смолами, які з'єднуються разом за допомогою методу високого тиску. Відповідно, такий матеріал є значно стійкішим до дії води і практично не змінює свої розміри під час занурення у воду та не дає змоги їй проникати у внутрішні шари ДПМ.

Висновки. Тип клею для приклеювання HPL icтотно не впливає на фізико-механічні властивості личкованих ДПМ, за винятком набрякання за товщиною після занурення у воді впродовж 24 год. Хоча застосування ПЕ плівки дає змогу отримати личковані ДПМ із дещо вищими показниками міцності та водостійкості, порівняно з ВПЕ чи без використання клею. Дещо меншими показниками міцності характеризуються личковані ДПМ із використанням ВПЕ. Показники набрякання за товщиною після занурення у воді впродовж 2 год личкованих ДПМ із різним типом клею для приклеювання HPL були практично однаковими. Набрякання за товщиною після 24 год занурення у воді істотно зменшується у разі використання клею для приклеювання HPL.

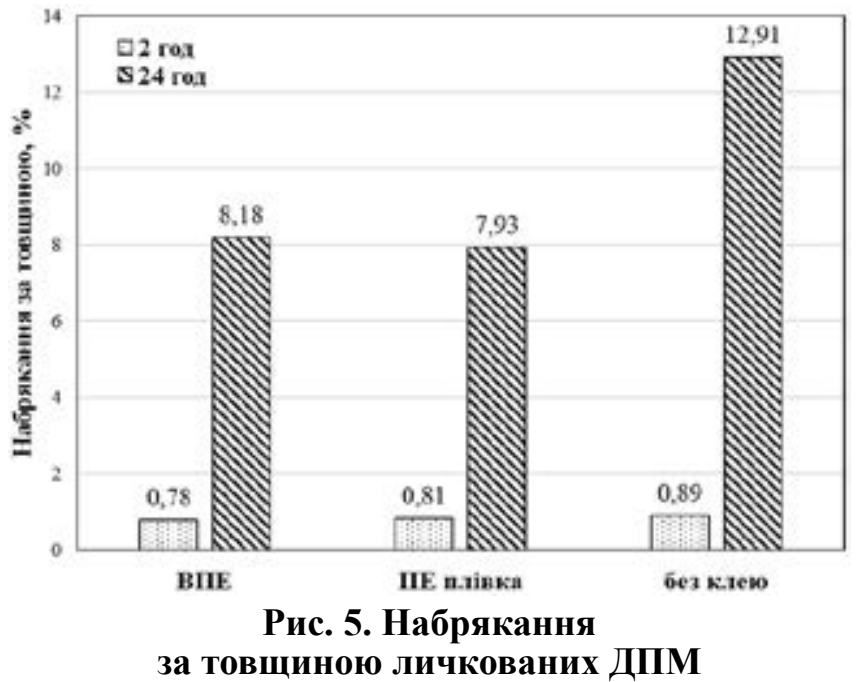

\section{СПИСОК ВИКОРИСТАНИХ ДЖЕРЕЛ}

1. Бехта П.А. Деревинно-полімерні композити на основі термопластичних полімерів / П.А. Бехта, П.В. Лютий. // Наукові праці Лісівничої академії наук України: зб. наук. праць. - 2010. - Вип. 8. - С. 11-17.

2. Klyosov A.A. Wood Plastic Composites / A.A. Klyosov. - New Jersey: John Wiley \& Sons, Hoboken, 2007. - 726 pp.

3. Rowell R.M. Handbook of wood chemistry and wood composites / R.M. Rowell. - Boca Raton: CRC Press, 2005. - 487 p.

4. Бехта П.А. Вплив різного типу модифікувальних добавок і їх сумішей на властивості деревинно-полімерних плит / П.А. Бехта, П.В. Лютий. // Наукові праці Лісівничої академії наук України: зб. наук. праць. - 2011. - Вип. 9. - С. 194-199.

5. Schmidt H. Processing and flexural properties of surface reinforced flat pressed WPC panels / H. Schmidt, J.T. Benthien, H. Thoemen // European Journal of Wood and Wood Products - Vol. 71, 2013. P. 591-597.

6. Istek A. The effect of décor paper and resin type on the physical, mechanical, and surface quality properties of particleboards coated with impregnated décor paper / A. Istek, D. Aydemir, S. Aksu. // BioResources Vol. 5(2), 2010. - P. 1074-1083.

7. Norvydas V. Strength and stiffness properties of furniture panels covered with different coatings. / Norvydas, V.; Minelga, D. Materials Science (MEDŽIAGOTYRA). - Vol. 12 (4), 2006. - P. 328-332.

8. Possibilities of single-stage pressing of veneered particleboards. / [P. Borysiuk, M. Zbiec, P. Boruszewski, M. Maminski, A. Mazurek] // Annals of Warsaw University of Life Sciences - SGGW Forestry and Wood Technology - Vol. 73. - 2011. - P. 172-175.

9. Bekhta P. Effects of different kinds of coating materials on flat pressed WPC panels // P.Bekhta, P. Lyutyy, G. Ortynska. // Drvna Industrija - Vol. 67(2). 2016. - P. 113-118. 


\section{П.В. Лютый, П.А. Бэхта, Г.Е. Ортынська \\ СВОЙСТВА ОБЛИЦОВАННЫХ ДРЕВЕСНО-ПОЛЕМИРНЫХ МАТЕРИАЛОВ ПЛОСКОГО СПОСОБА ПРЕССОВАНИЯ}

Исследован процесс облицовки древесно-полимерных материалов (ДПМ) плоского способа прессования. Облицованные ДПМ осуществляли одновременно с их прессованием. В качестве облицовочного материала использован декоративный ламинат высокого давления (HPL) толщиной 0,5 мм. Как клей для приклеивания HPL использованы полиэтиленовая (ПЭ) пленка или вторичный полиэтилен низкой плотности (ВПЭ). Процесс прессования и облицовки ДПМ происходил в одну стадию (одновременно). Для сравнения, изготавливали облицованные ДПМ без использования клея для приклеивания HPL. Определены следующие показатели ДПМ: предела прочности и модуля упругости при статическом изгибе, предел прочности при растяжении перпендикулярно плоскости плиты, набухание по толщине в 2 и 24 ч. Установлено, что тип клея не оказывает существенного влияния на механические показатели ДПМ. Хотя предел прочности при статическом изгибе в случае использования ВПЭ возрастает на $14 \%$, а при использовании ПЭ пленки - на $24 \%$ по сравнению с облицованными ДПМ без использования клея для приклеивания HPL. Аналогические зависимости установлены и для модуля упругости при статическом изгибе. Во время облицовки ДПМ без использования клея наблюдается непосредственный контакт между HPL и древесно-полимерной композицией (в которой доминируют древесные частицы). Соответственно, этот контакт не способствует образованию прочного адгезионного соединения и при испытании происходит быстрое его разрушение. Использование же клея способствует образованию прочной адгезионной связи между облицовочным материалом и подкладкой. Тип клея для приклеивания HPL также не имеет определяющего влияния на предел прочности при растяжении перпендикулярно плоскости плиты. Набухание по толщине после 2 ч вымачивания в воде во всех облицованных ДПМ практически одинаковое и ниже показателя $1 \%$. С увеличением продолжительности вымачивания образцов до 24 ч характер влияния типа клея становится более выраженным. При использовании ВПЭ набухания по толщине (за 24 ч вымачивания) уменьшается в 1,6 раза, а в случае использования ПЭ пленки - в 1,63 раза, по сравнению с облицованные ДПМ без использования клея для приклеивания HPL, в случае использования ПЭ пленки и ВПЭ наблюдаются практически одинаковые результаты набухания по толщине как за 2, так и за 24 ч вымачивания.
Ключевые слова: древесно-полимерный материал, облицовка, полиэтиленовая пленка, вторичный полиэтилен низкой плотности, декоративный ламинат высокого давления, плоское прессование

\section{P. Lyutyy, P. Bekhta, G. Ortynska}

\section{PROPERTIES OF LAMINATED FLAT PRESSED WOOD PLASTIC COMPSITES}

The process of laminating of flat pressed wood plastic composites (WPC) and their properties was studied in this paper. Two-side laminating process of WPC panels was carried out simultaneously with their flat pressing. Modification additives were not used for the production of WPC. High pressure laminates (HPL) with the thickness $0.5 \mathrm{~mm}$ were used as the laminating material. Recycled polyethylene (rPE) and polyethylene (PE) film were used as gluing material for HPL bonding. The laminating of WPC with HPL without glue was produced at the same production parameters. Modulus of rupture (MOR), modulus of elastic (MOE), internal bond (IB) and thickness swelling after 2 (TS/2) and 24 (TS/24) hours were investigated of laminated flat pressed WPC. It was found that the type of glue has not significant influence on the mechanical properties of laminated WPC. The highest values of MOR and MOE were observed in laminated WPC with the using of PE film. A little bit lower values were observed in laminated WPC with the using of rPE. In particular, the increase of MOR was $14 \%$ with using of RPE and $24 \%$ with using of PE film in compare with laminated WPC without glue. The same depends were observed at the investigation of MOE. The values of the MOR (MOE) were higher than $29 \mathrm{~N} / \mathrm{mm} 2$ for all investigated types of laminated WPC. The type of glue has any influence on the IB of laminated WPC. This influence was confirmed by ANOVA test. The values of IB were at value 0.33$0.34 \mathrm{~N} / \mathrm{mm}^{2}$. The type of the glue has significant influence on the TS/24 of laminated WPC. But the TS/2 of the investigated laminated WPC was at the same level (less than 1\%). In particular, the TS/24 decreased in 1.6 times by the using of $\mathrm{rPE}$ and in 1.63 times by the using of PE film in comparison with laminated WPC without using glue. It should be noted that the values of TS/2 and TS/24 were the same for laminated WPC with using of $\mathrm{rPE}$ and PE film. The highest values of the TS/24 were $12.91 \%$, which is less than standard norm for wood based panels. The WPC laminated by HPL have high strength, water resistance and could be used at different areas, in particular in furniture production.

Key words: wood plastic composites, laminating, polyethylene film, recycled polyethylene, high pressure laminate, flat pressing 